\title{
Lutospawanie łukowe stopów aluminium z tytanem i stalą ocynkowaną
}

\author{
Arc braze welding of aluminium alloy \\ with titanium and galvanized steel
}

\section{Streszczenie}

Przedstawiono wyniki badań technologicznych z zakresu lutospawania łukowego metodą TIG stopu aluminium AW5754 (AIMg3) z tytanem oraz lutospawania metodą TIG i niskoenergetyczną metodą MIG prądem przemiennym z pulsacją stopu aluminium AW-6061 (AIMgSi) ze stalą niestopową, ocynkowaną galwanicznie (blacha karoseryjna) DC03+ZE. W badaniach zastosowano spoiwo aluminiowe (Al99,5) i spoiwa na osnowie stopów Al-Si (AlSi5, AlSi12). Połączenia lutospawane poddano badaniom: wytrzymałościowym, metalograficznym oraz strukturalnym z zastosowaniem elektronowego mikroskopu skaningowego i spektrometru z dyspersją energii promieniowania rentgenowskiego (EDS). Opracowano najkorzystniejsze warunki i parametry lutospawania z uwagi na jakość i wytrzymałość połączeń, determinowaną w znacznym stopniu występowaniem na granicach złączy kruchych faz międzymetalicznych.

Słowa kluczowe: lutospawanie TIG i MIG; stopy aluminium, tytan; właściwości mechaniczne połączeń lutospawanych; parametry lutospawania

\section{Abstract}

The article presents the results of technological tests related to TIG-based arc braze welding of titanium with AW5754 (AIMg3) aluminium alloy and the results of TIG and low-energy MIG AC pulse braze welding of aluminum alloy AW-6061 (AlMgSi) with unalloyed, galvanized steel DC03 + ZE. The tests involved the use of an aluminium filler metal (Al99.5) and two filler metals based on Al-Si alloys (AISi5 and AlSi12). Braze welded joints underwent tensile tests, metallographic examinations using a light microscope as well as structural examinations involving the use of a scanning electron microscope and an X-ray energy dispersive spectrometer (EDS). Developed the most favorable conditions and braze welding parameters due to the quality and strength of joints that is determined the presence of brittle intermetallic phases on the borders of joints.

Keywords: TIG and MIG braze welding; aluminium alloy; titanium; mechanical properties of braze welded joints; structural properties of braze welded joints; braze welding parameters

\section{Wstęp}

Dynamicznie rozwijający się przemysł motoryzacyjny, chemiczny oraz lotniczy, wymaga wykonywania połączeń materiałów, znacznie różniących się właściwościami fizyko - chemicznymi. Związane jest to z wciąż ważnym i aktualnym zagadnieniem obniżania masy oraz kosztów materiałowych elementów, przy jednoczesnym podwyższaniu ich właściwości eksploatacyjnych i odporności na niekorzystne warunki środowiskowe. Do tego rodzaju połączeń należą połączenia tytanu, stali (niestopowych, ocynkowanych - karoseryjnych, nierdzewnych) z metalami lekkimi, zwłaszcza $z$ aluminium i jego stopami. Konieczność wykonania tego typu połączeń istnieje m.in. w: podzespołach osprzętu lotniczego, aparaturze kriogenicznej, wymiennikach ciepła, instalacjach chemicznych, sprzęcie gospodarstwa domowego, elementach obudów w urządzeń transportowych, konstrukcjach nadbudówek statków oraz nadwozi i osprzętu nowoczesnych pojazdów samochodowych [1,2].

W przypadku materiałów różnoimiennych takich jak tytan i aluminium podstawowe trudności występujące podczas ich łączenia metodami spawalniczymi to: różnice w temperaturach topnienia, przewodności, rozszerzalności cieplnej oraz ich wysoka reaktywność z gazami z otoczenia i wzajemne tworzenie kruchych faz międzymetalicznych w strefie

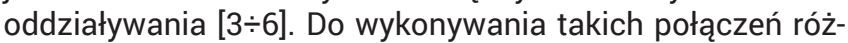
noimiennych zaleca się stosować nieliczne, specjalistyczne metody spawania (spawanie elektronowe, laserowe) i zgrzewania (zgrzewanie dyfuzyjne, tarciowe klasyczne i FSW), lutowanie twarde dyfuzyjne oraz lutospawanie tukowe i laserowe $[7 \div 9,17,18]$. Nieliczne, dostępne publikacje z zakresu lutospawania łukowego powyższych materiałów, przedstawiające w sposób fragmentaryczny przykłady takich zastosowań świadczą, że zagadnienie to jest wciąż na etapie badań laboratoryjnych $[10,11]$.

Łączenie metodami spawalniczymi stopów żelaza (stali) $z$ aluminium, stanowiące wciąż aktualny problem zarówno badawczy jak i technologiczny, jest trudne z uwagi na zróżnicowane właściwości fizyczne oraz chemiczne łączonych materiałów oraz skłonność do tworzenia faz międzymeta-

Dr inż. Dawid Majewski; dr inż. Andrzej Winiowski, prof. nzw. w IS - Instytut Spawalnictwa, Gliwice.

Autor korespondencyjny/Corresponding author: dawid.majewski@is.gliwice.pl 
licznych - aluminidków żelaza, obniżających właściwości

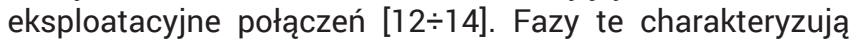
się wysoką kruchością i twardością $\left(\mathrm{Fe}_{2} \mathrm{Al}_{5}-1100 \mathrm{HV}, \mathrm{FeAl}_{3}\right.$ - 900HV, $\mathrm{Fe}_{2} \mathrm{Al}_{7}-650 \mathrm{HV}, \mathrm{FeAl}_{2}-1000 \mathrm{HV}$, FeAl $-500 \mathrm{HV}$, $\left.\mathrm{Fe}_{3} \mathrm{Al}-350 \mathrm{HV}\right)[5,12]$. Powstawanie ich od strony Fe w postaci warstw w strefach granicznych - dyfuzyjnych złączy tych metali lub ich stopów, wykonanych spawalniczymi metodami łączenia jest nieuchronne, gdyż warunkują one powstanie trwałego, metalicznego połączenia. W publikacjach z zakresu lutowania twardego i lutospawania stali z aluminium i jego stopami uznano te właśnie metody łączenia za korzystniejsze od spawania łukowego $[15,16]$.

W niniejszym artykule przedstawiono wyniki badań technologicznych z zakresu lutospawania łukowego metodą TIG stopu aluminium AW-5754 (AlMg3) z tytanem oraz lutospawania metodą TIG i niskoenergetyczną metodą MIG prądem przemiennym z pulsacją stopu aluminium AW-6061 (AlMgSi) ze stalą niestopową, ocynkowaną galwanicznie (blacha karoseryjna) DC03+ZE.

\section{Materiały podstawowe i dodatkowe zastosowane $\mathrm{w}$ badaniach}

W badaniach zastosowano następujące materiały podstawowe w postaci próbek o wymiarach 150x70x1,5 mm wyciętych z blach:

- tytanowej w gat. Grade 2 wg ASTM B265;

- ze stali niestopowej, ocynkowanej galwanicznie (blachy karoseryjne) w gat. DC03+ZE wg PN-EN 10152:2011;

- ze stopu aluminium w gat. AW-6061 (Al-Mg-Si) wg PN-EN 573-3:2014,

- ze stopu aluminium w gat. AW-5754 (AIMg3) wg PN-EN 573-3:2014.

Lutospawanie prowadzono przy zastosowaniu spoiw typu: Al-Si (AISi12, AISi5) i spoiwa aluminiowego (Al99,5) w postaci pręta o $\emptyset 2,4 \mathrm{~mm}$ dla metody TIG oraz drutu $\emptyset$ 1,2 mm dla metody MIG (wg PN-EN ISO 18273:2007). Jako gaz osłonowy zastosowano argon (gat. 11 wg PN-EN
ISO 14175:2009). Próbki przed procesem lutospawania odtłuszczano acetonem (nie trawiono). Ponadto w procesie lutospawania metodą TIG dla układu materiałowego stal ocynkowana galwaniczne - stop aluminium AW-6061 zastosowano niekorozyjny topnik fluoroglinianowy Nocolok firmy Solvay.

\section{Przebieg i wyniki badań lutospawania tukowego metoda TIG stopu aluminium AW-5754 (AlMg3) z tytanem}

Proces lutospawania próbek tytanowych z próbkami ze stopu aluminium AIMg3 metodą TIG przeprowadzono ręcznie na urządzeniu spawalniczym MagicWave 500 firmy Fronius, przy zastosowaniu źródła prądu przemiennego oraz elektrody wolframowej torowanej typu WT10 wg PN-EN ISO 6848:2007 (kąt ukosowania elektrody 90). Próbki blach w badaniach układano na zakładkę, zarówno w układzie próbka tytanowa na próbce ze stopu aluminium jak i odwrotnie. Przeprowadzone badania technologiczne pozwoliły zaobserwować, że najlepszą jakością lutospoin charakteryzują się złącza wykonane z zastosowaniem spoiwa Al99,5 (Al 1050) o średnicy $\emptyset 2,4$ (tabl. I). Dodatkowo zaobserwowano, że w przypadku lutospawania złączy zakładkowych tym spoiwem, lepszą jakość połączeń otrzymuje się przy ułożeniu próbki tytanowej na górze, a aluminiowej na dole. Ten sposób ułożenia korzystniej wpływa na zwilżalność spoiwem powierzchni tytanu. Najniższą jakość lutospoin uzyskano dla złączy zakładkowych przy ułożeniu próbki ze stopu aluminium na tytanowej i zastosowaniu spoiwa AlSi12. Ponadto zastosowanie tego spoiwa przy ułożeniu próbki tytanowej na próbce ze stopu aluminium prowadzi do występowania niestabilnego "łuku błądzącego". Również w przypadku stosowania spoiwa AISi12 zaobserwowano, że należy stosować większe natężenie prądu lutospawania

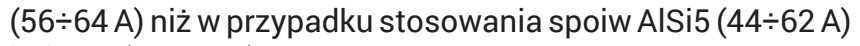

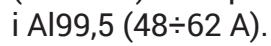

Tablica I. Próbne lutospoiny złączy zakładkowych wykonanych ze stopu aluminium AW-5754 (AIMg3) z tytanem Grade 2, przy zastosowaniu spoiwa Al99,5 o średnicy 2,4 mm

Table I. Tests brazewelds of overlap joints of aluminum alloy AW-5754 (AlMg3) with titanium Grade 2, using Al99.5 filler metals $\varnothing 2.4$

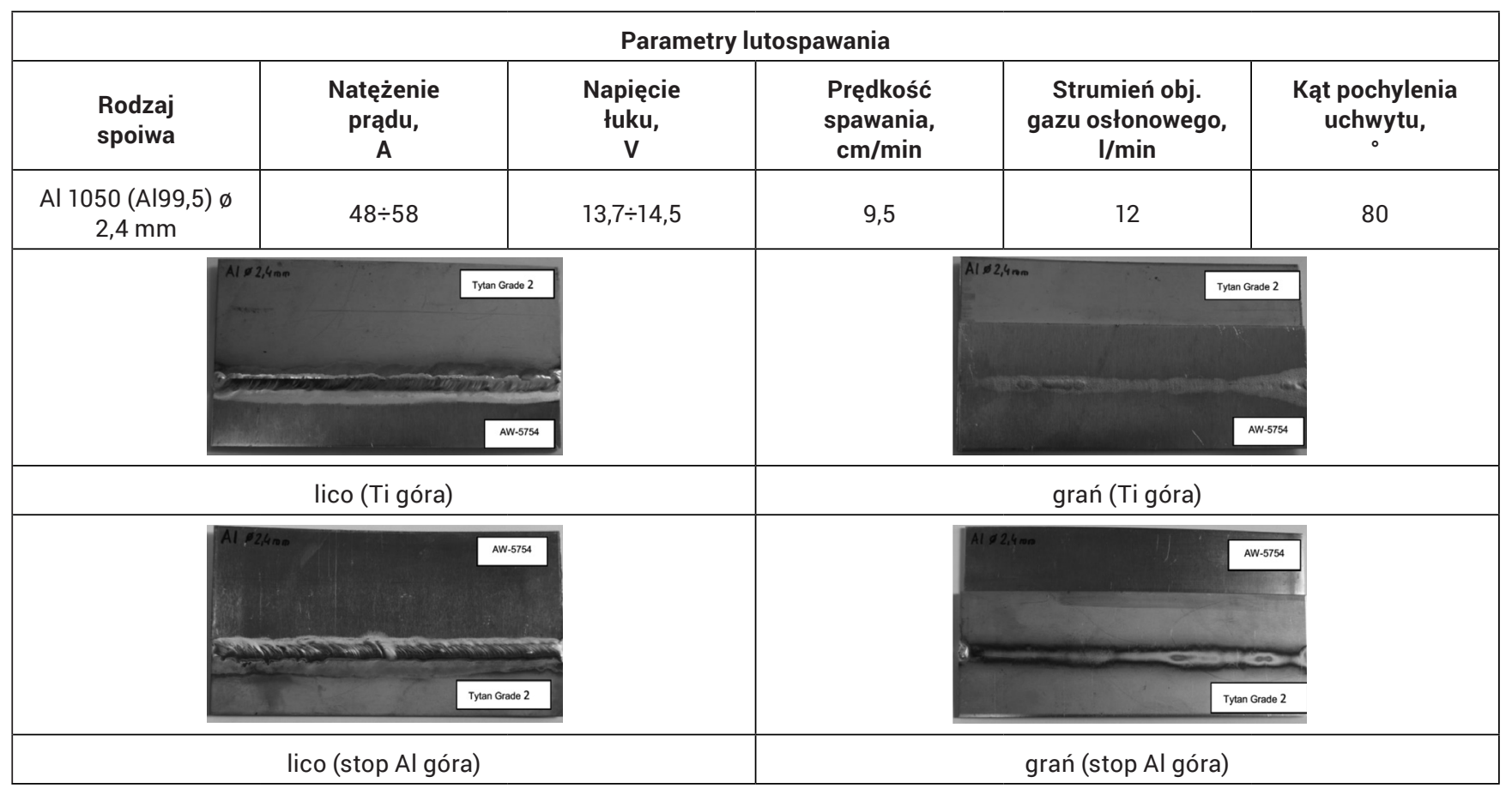


W celu określenia właściwości wytrzymałościowych (maksymalnej siły niszczącej, wytrzymałości na rozciąganie $\mathrm{Rm}$ ) wykonano tytanowo - aluminiowe złącza doczołowe i przeprowadzono próbę statycznego rozciągania w temperaturze otoczenia. Badania przeprowadzono na maszynie wytrzymałościowej firmy Instron model 4210, o zakresie pomiarowym do $600 \mathrm{kN}$, wyposażonej w system komputerowej rejestracji i archiwizacji wyników badań.

Badania wytrzymałości na rozciąganie prowadzono dla trzech próbek dla każdego spoiwa (Al99,5, AlSi5 oraz AlSi12). Wyniki badań po przeprowadzonej obróbce statystycznej przedstawiono w tablicy II. Zerwanie we wszystkich przypadkach wystąpiło w lutospoinie od strony tytanu. Na podstawie uzyskanych wyników można zaobserwować, że największą wytrzymałość na rozciąganie wynoszącą ok. $115 \mathrm{MPa}$, uzyskano dla złączy wykonanych przy zastosowaniu spoiwa Al99,5. Natomiast w przypadku pozostałych spoiw (AISi5, AlSi12) wytrzymałość na rozciąganie była

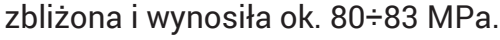

Tablica II. Wytrzymałość na rozciąganie połączeń tytan Grade 2 - stop AW-5754 lutospawanych metodą TIG, przy zastosowaniu spoiw: Al99,5, AlSi5 oraz AlSi12

Table II. Tensile strength of titanium Grade 2 - aluminium alloy AW- 5754 butt joints, braze welding TIG method for each filler metal, i.e. Al99.5, AlSi5 and AlSi12

\begin{tabular}{|c|c|c|c|c|}
\hline \multirow{2}{*}{ Lp. } & \multirow{2}{*}{$\begin{array}{c}\text { Rodzaj } \\
\text { spoiwa }\end{array}$} & $\begin{array}{c}\text { Maksymalna } \\
\text { siła niszcząca, } \\
\text { kN }\end{array}$ & \multicolumn{2}{|c|}{$\begin{array}{c}\text { Wytrzymałość na rozciąganie, } \\
\text { MPa }\end{array}$} \\
\cline { 3 - 5 } & $\begin{array}{c}\text { Wartość } \\
\text { średnia* }\end{array}$ & $\begin{array}{c}\text { Wartość } \\
\text { średnia* }\end{array}$ & $\begin{array}{c}\text { Odchyl. } \\
\text { standard. }\end{array}$ \\
\hline 1 & Al99,5 & 10,77 & 115,85 & 23,75 \\
\hline 2 & AlSi5 & 7,76 & 82,97 & 12,16 \\
\hline 3 & AlSi12 & 7,32 & 80,30 & 13,72 \\
\hline * - wartość średnia z 3 pomiarów \\
\hline \multicolumn{5}{|l}{} \\
\hline
\end{tabular}

Próbki do makroskopowych badań metalograficznych przygotowywano dokonując przekrojów poprzecznych przygotowanych wcześniej złączy zakładkowych, a następnie poddano je szlifowaniu i trawieniu w odczynniku Kroll'a. Dokumentację fotograficzną wykonywano za pomocą aparatu cyfrowego OLYMPUS Camedia. Wyniki dla najkorzystniejszego spoiwa Al99,5 przedstawiono na rysunku 1.
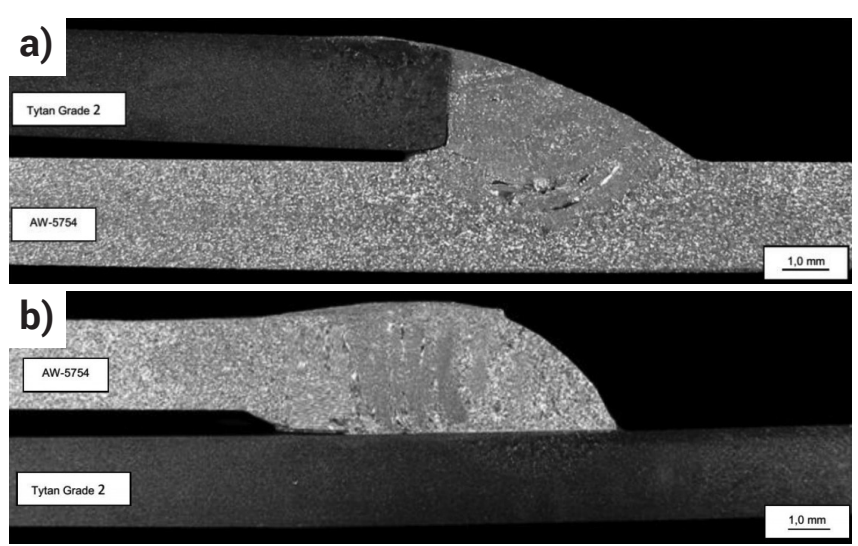

Rys. 1. Makrostruktura złącza zakładkowego tytan Grade 2 - stop AW-5754 lutospawanego spoiwem Al99,5 o średnicy $\varnothing 2,4 \mathrm{~mm}$ w układzie tytan u góry (a) i tytan u dołu (b), traw. odcz. Kroll'a Fig. 1. Macrostructure of the overlap joints of Grade 2 titanium - aluminium alloy AW-5754 braze welded with Al99.5 filler metal $\emptyset 2.4 \mathrm{~mm}$, titanium on the top (a) titanium at the bottom (b), chemical etching using Kroll's reagent
Na podstawie przeprowadzonych badań stwierdzono najlepszej jakości lutospoinę przy ułożeniu próbki tytanowej na próbce ze stopu aluminium. Takie ułożenie zapewnia bowiem znacznie mniejszy kąt zwilżenia spoiwem tytanu a zatem lepszą jego zwilżalność. W przeciwnym przypadku kształt przekroju lutospoiny świadczy o gorszej zwilżalności tytanu. W uzyskanych lutospoinach stwierdzono nieistotne niezgodności lutownicze, nie wpływające znacząco na właściwości połączeń.

Badania strukturalne złączy lutospawanych metodą TIG prowadzono z użyciem mikroskopu elektronowego skaningowego (SEM - Scanning Electron Microscope) Hitachi S-3400N w technice elektronów wstecznie sprężyście rozproszonych (BSE - Back-Scattered Electrons), a mikroanalizę punktową składu chemicznego faz w strukturach złączy przeprowadzono metodą spektroskopii za pomocą spektrometru z dyspersją energii promieniowania rentgenowskiego (EDS) typu Thermo Noran System Six, współpracującego z mikroskopem elektronowym. Badaniom poddano doczołowe złącza próbne lutospawane spoiwem aluminiowym Al99,5, a w szczególności przyległą do tytanu część złącza. Tam występowało połączenie lutowane (od strony stopu aluminium połączenie spawane) i następowało rozdzielanie próbek w badaniach wytrzymałości. Wyniki przeprowadzonych badań przedstawiono na rysunku 2 .

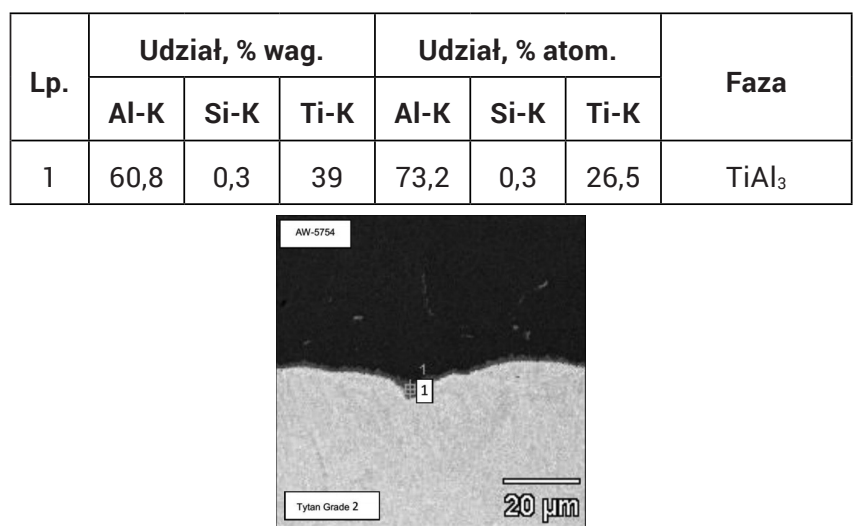

Rys. 2. Mikrostruktura złącza doczołowego tytan Grade 2 - stop AW-5754 (strefa dyfuzyjna od strony tytanu), lutospawanego spoiwem Al99,5 oraz analiza punktowa faz (mikroskop skaningowy - spektrometr EDS)

Fig. 2. Microstructure of the butt joint of Grade 2 titanium - aluminium alloy AW-5754 (diffusion zone from the titanium), braze welded Al99.5 filler metal with EDS measurements in 1 point

\section{Przebieg i wyniki badań lutospawania łukowego metodą TIG i niskoenergetyczną metodą MIG prądem przemiennym z pulsacją stopu aluminium AW-6061 (AIMgSi) ze stalą niestopową, ocynkowaną galwanicznie DC03+ZE}

Proces lutospawania metodą TIG prowadzono ręcznie na stanowisku spawalniczym, wyposażonym w urządzenie spawalnicze V40 firmy LORCH, przy zastosowaniu prądu przemiennego. Urządzenie to umożliwia regulację biegunowości prądu w zakresie $10 \div 90 \%$ okresu, w którym elektroda wolframowa jest biegunem dodatnim, dzięki czemu można również sterować ilością wprowadzonego ciepła do złącza. Jako najkorzystniejszy na podstawie przeprowadzonych wstępnych prób lutospawania ustalono zakres 20\% i taki zastosowano w dalszych próbach lutospawania. Natomiast proces lutospawania metodą MIG prądem przemiennym 
Tablica III. Próbne lutospoiny złączy zakładkowych wykonanych ze stali ocynkowanej niskostopowej DC03+ZE ze stopem aluminium AW-6061, wykonanych metodą TIG przy zastosowaniu spoiw AISi5 i AISi1 2 o średnicy 2,4 mm oraz topnika Nocolok

Table III. Tests brazewelds of overlap joints of galvanized steel DC03+ZE with aluminum alloy AW-6061, using TIG technique with two filler metals AISi5 and AISi12 ø 2.4 and flux Nocolok

\begin{tabular}{|c|c|c|c|c|c|}
\hline \multicolumn{6}{|c|}{ Parametry lutospawania } \\
\hline $\begin{array}{l}\text { Rodzaj } \\
\text { spoiwa }\end{array}$ & $\begin{array}{l}\text { Natężenie } \\
\text { prądu, } \\
\text { A }\end{array}$ & $\begin{array}{l}\text { Napięcie } \\
\text { tuku, } \\
\text { V }\end{array}$ & $\begin{array}{l}\text { Prędkość } \\
\text { spawania, } \\
\text { cm/min }\end{array}$ & $\begin{array}{c}\text { Strumień obj. } \\
\text { gazu osłonowego, } \\
\text { I/min }\end{array}$ & $\begin{array}{c}\text { Kąt pochylenia } \\
\text { uchwytu, } \\
\circ\end{array}$ \\
\hline $\begin{array}{l}\text { Al 4043(AlSi5) - } \\
\text { próbka nr 13FT }\end{array}$ & $68 \div 74$ & $16,5 \div 16,8$ & 8,6 & 12 & 80 \\
\hline $\begin{array}{l}\text { Al 4047(AISi12) - } \\
\text { próbka nr 18FT }\end{array}$ & $62 \div 68$ & $16,2 \div 16,9$ & 9 & 12 & 80 \\
\hline & 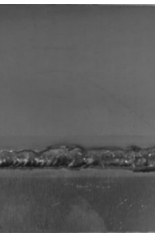 & & & 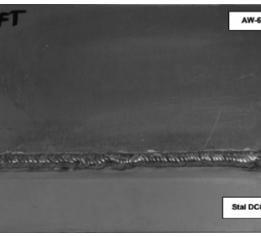 & \\
\hline
\end{tabular}

Tablica IV. Próbne lutospoiny złączy zakładkowych wykonanych ze stali ocynkowanej niskostopowej DC03+ZE ze stopem aluminium AW-6061, wykonanych metodą MIG przy zastosowaniu spoiw AlSi5 i AlSi1 2 o średnicy 1,2 mm

Table IV. Tests brazewelds of overlap joints of galvanized steel DC03+ZE with aluminum alloy AW-6061, using MIG technique with two filler metals AlSi5 and AlSi12 ø $1.2 \mathrm{~mm}$

\begin{tabular}{|c|c|c|c|c|c|c|c|}
\hline \multicolumn{8}{|c|}{ Parametry lutospawania } \\
\hline $\begin{array}{l}\text { Rodzaj } \\
\text { spoiwa }\end{array}$ & $\begin{array}{c}\text { Natężenie } \\
\text { prądu, } \\
\text { A }\end{array}$ & $\begin{array}{c}\text { Napięcie } \\
\text { łuku, } \\
\text { V }\end{array}$ & $\begin{array}{c}\text { Prędkość } \\
\text { spawania, } \\
\text { cm/min }\end{array}$ & $\begin{array}{c}\text { Strumień obj. } \\
\text { gazu } \\
\text { osłonowego, } \\
\text { I/min }\end{array}$ & $\begin{array}{c}\text { Udział } \\
\text { składowej } \\
\text { ujemnej, \% }\end{array}$ & $\begin{array}{c}\text { Prędkość } \\
\text { podawania } \\
\text { drutu, m/min }\end{array}$ & $\begin{array}{l}\text { Kąt pochyle- } \\
\text { nia uchwytu, } \\
\circ\end{array}$ \\
\hline $\begin{array}{c}\text { Al } 4043 \\
\text { (AISi5) } \\
\text { - próbka nr } 21\end{array}$ & $51 \div 56$ & $17,1 \div 17,7$ & 60 & 12 & 50 & 3,0 & 10 \\
\hline $\begin{array}{c}\text { Al } 4047 \\
\text { (AlSi12) } \\
\text { - próbka nr } 37\end{array}$ & $49 \div 56$ & $17,1 \div 17,4$ & 55 & 12 & 50 & 2,2 & 10 \\
\hline \multicolumn{8}{|c|}{21} \\
\hline
\end{tabular}

z pulsacją prowadzono na zmechanizowanym stanowisku spawalniczym, wyposażonym w urządzenie spawalnicze DW 300 firmy OTC Daihen. Urządzenie to umożliwia ustawienie współczynnika składowej ujemnej $\left(\mathrm{EN}_{\mathrm{w}}\right)$, który określa procentowy udział ujemnej polaryzacji elektrody w przebiegu prądu spawania.

Badania technologiczne przeprowadzono wykonując złącza zakładkowe blach stali ocynkowanej (DC03+ZE) ze stopem aluminium (AW-6061) przy naprzemiennym ułożeniu elementów tj. próbka stalowa na próbce ze stopu aluminium i odwrotnie.

Złącza wykonane przy zastosowaniu spoiw typu Al-Si (AISi5 i AISi12) charakteryzowały się dobrą jakością, natomiast złącza wykonane przy zastosowaniu spoiwa z czystego aluminium $(A 199,5)$ wykazywały znaczną kruchość i skłonność do pękania po lutospawaniu. Z tego też względu w dalszych badaniach stosowano wyłącznie spoiwa typu Al-Si. Wyniki przeprowadzonych prób przedstawiono w tablicy III i IV.

Dla najkorzystniejszych spoiw wytypowanych na podstawie prób technologicznych przeprowadzono badania makroskopowe, wytrzymałościowe oraz strukturalne.
Próbki do badań metalograficznych pobierano dokonując przekrojów poprzecznych przygotowanych wcześniej złączy zakładkowych uzyskanych w badaniach technologicznych. Wyniki makroskopowych badań metalograficznych dla złączy o najkorzystniejszej jakości przedstawiono na rysunkach 3 i 4.

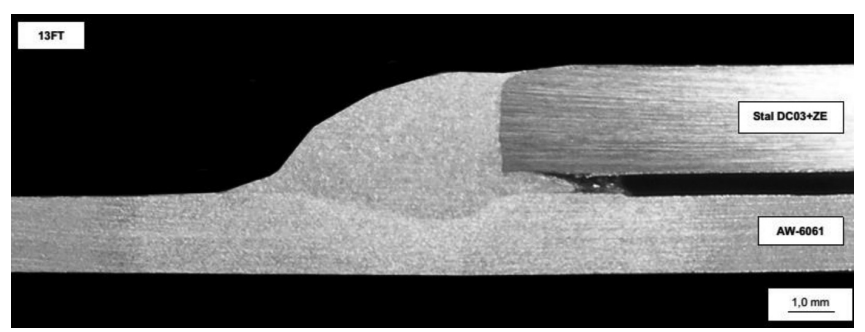

Rys. 3. Makrostruktura złącza zakładkowego stali ocynkowanej typu DC03+ZE ze stopem aluminium AW-6061 lutospawanego metoda TIG z użyciem spoiwa AISi5 $\mathrm{i}$ topnika fluoroglinianowego, traw. odcz. Kroll'a Fig. 3. Macrostructure of the overlap joint of galvanized steel DC03+ZE with aluminum alloy AW-6061, braze welded TIG technique with filler metal AISi5 and Nocolok flux, chemical etching using Kroll's reagent 


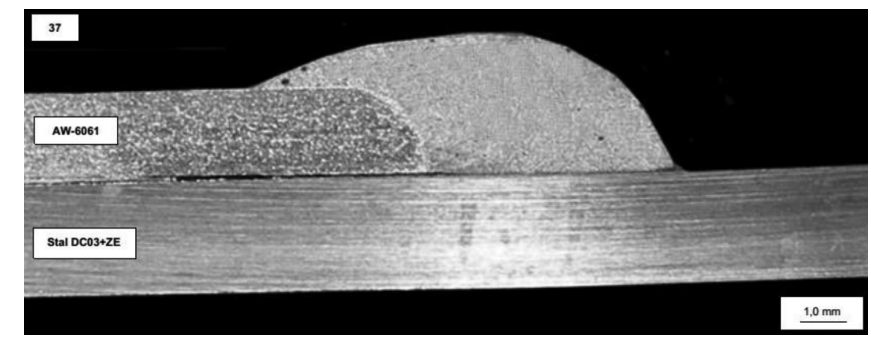

Rys. 4. Makrostruktura złącza zakładkowego stali ocynkowanej typu DC03+ZE ze stopem aluminium AW-6061 lutospawanego metoda MIG z użyciem spoiwa AISi12, traw. odcz. Kroll'a

Fig. 4. Macrostructure of the overlap joint of galvanized steel DC03+ZE with aluminum alloy AW-6061, braze welded MIG technique with filler metal AISi12, chemical etching using Kroll's reagent

Badania wytrzymałości na ścinanie przeprowadzono na trzech próbkach dla złączy oznaczonych nr 13FT oraz 37 (tabl. III i IV). Wyniki po przeprowadzonych badaniach oraz obróbce statystycznej przedstawiono w tabl. V. Zerwanie złączy następowało na granicy lutospoiny ze stopem aluminium.

Badania metalograficzne mikroskopowe i analizę struk-

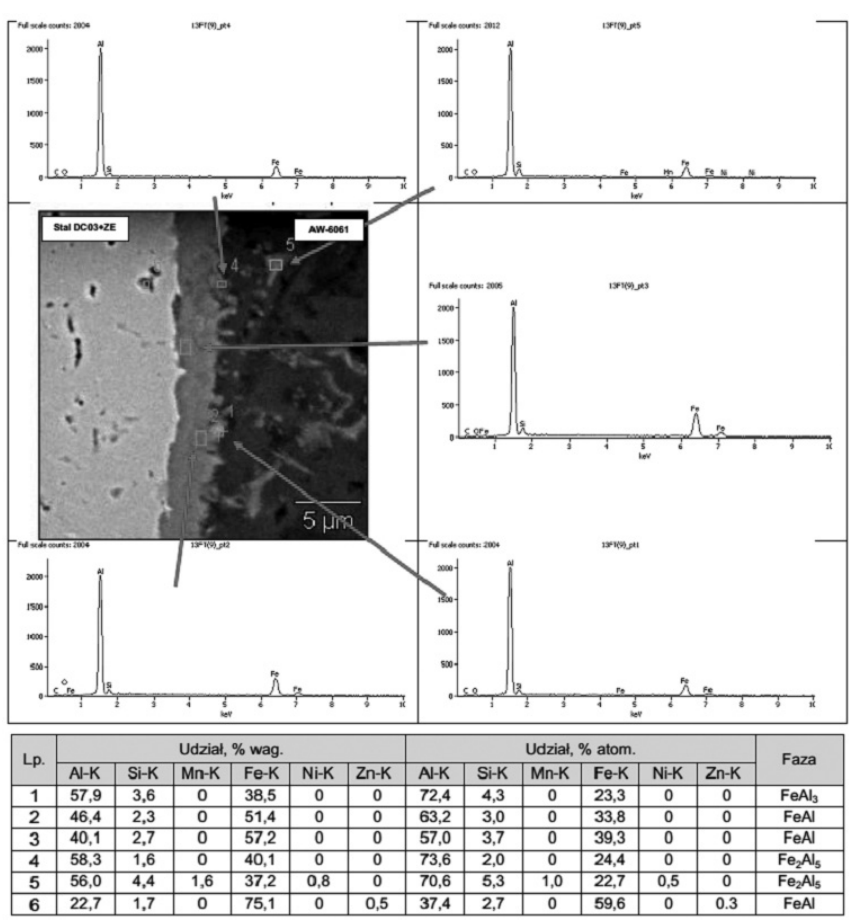

Rys. 5. Mikrostruktura złącza zakładkowego stali ocynkowanej typu DC03+ZE ze stopem aluminium AW-6061 (nr 13FT) lutospawanego metoda TIG z użyciem spoiwa AISi5 i topnika fluoroglinianowego oraz analiza punktowa faz (mikroskop skaningowy - spektrometr EDS, pomiar w 6 punktach)

Fig. 5. Microstructure of the overlap joint of galvanized steel DC03+ZE with aluminum alloy AW-6061 (no. 13FT), braze welded TIG technique with filler metal AISi5 and Nocolok flux, EDS measurements in 6 points
Tablica V. Właściwości wytrzymałościowe lutospawanych połączeń stali ocynkowanej typu DC03+ZE ze stopem aluminium AW-6061

Table V. Mechanical properties braze welded joints of galvanized steel DC03+ZE with aluminum alloy AW-6061

\begin{tabular}{|c|c|c|c|}
\hline \multirow{2}{*}{ Lp. } & \multirow{2}{*}{$\begin{array}{c}\text { Oznaczenie } \\
\text { złącza }\end{array}$} & \multicolumn{2}{|c|}{ Maksymalna siła niszcząca, kN } \\
\cline { 3 - 4 } & & Wartość średnia* & Odchyl. standard. \\
\hline 1 & $13 \mathrm{FT}$ & 1,53 & 0,62 \\
\hline 2 & 37 & 2,28 & 0,36 \\
\hline \multicolumn{2}{|l}{} \\
\hline
\end{tabular}

turalną przeprowadzono w obszarach lutospoin przyległych do stali. Tam bowiem występowało połączenie lutowane (od strony stopu aluminium połączenie spawane) i następowało rozdzielanie próbek $\mathrm{w}$ badaniach wytrzymałości, determinowane istnieniem warstwy kruchych i twardych faz międzymetalicznych. Próbki złączy przed badaniami mikroskopowymi zainkludowano, a zgłady metalograficzne wykonywano przez szlifowanie na papierach SiC i polerowanie na pastach diamentowych i na zawiesinie SiO2. Wyniki przeprowadzonych badań przedstawiono na rysunkach 5 i 6 .

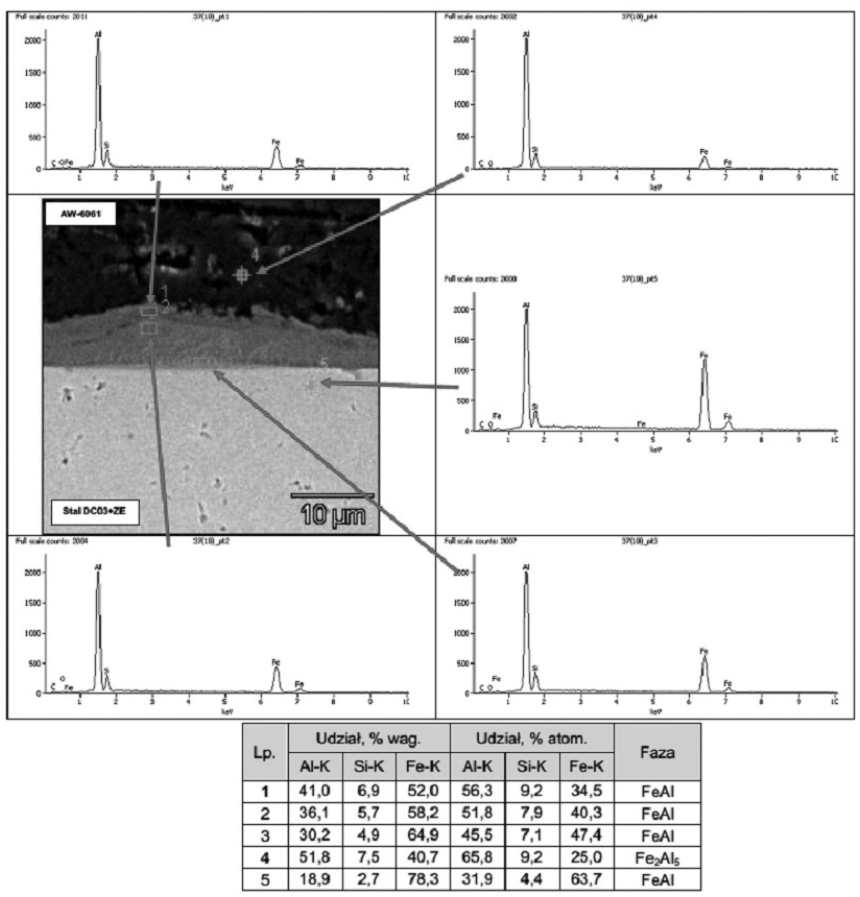

Rys. 6. Mikrostruktura złącza zakładkowego stali ocynkowanej typu DC03+ZE ze stopem aluminium AW-6061 (nr 37) lutospawanego metoda MIG z użyciem spoiwa AlSi12 oraz analiza punktowa faz (mikroskop skaningowy - spektrometr EDS, pomiar w 5 punktach) Fig. 6. Microstructure of the overlap joint of galvanized steel DC03+ZE with aluminum alloy AW-6061 (no. 37), braze welded MIG technique with filler metal AISi12, EDS measurements in 5 points

\section{Podsumowanie}

Wykonanie połączeń z materiałów różnoimiennych takich jak tytanu Grade 2 - stop aluminium AW-5754 jest możliwe dzięki zastosowaniu lutospawania metodą TIG. Połączenia tego rodzaju charakteryzują się dobrą jakością i wymaganymi właściwościami wytrzymałościowymi charakterystycznymi dla stopów aluminium. Najwyższą wytrzymałość na rozciąganie wynoszącą $115 \mathrm{MPa}$ uzyskano w przypadku zastosowania spoiwa Al 1050 (Al99,5). W przypadku tego układu materiałowego duże znaczenie ma również odpowiednie ułożenie próbek materiałów podstawowych. Doświadczanie wykazano, 
że najlepszą jakością charakteryzują się lutospoiny wykonane przy ułożeniu blachy tytanowej na górze, co sprzyja lepszemu zwilżeniu tytanu przez spoiwo oraz otrzymaniu lutospoin pozbawionych niezgodności lutowniczych. Przeprowadzone badania strukturalne złączy lutospawanych blach tytanowej i ze stopu aluminium AW-5754, wykonane z użyciem mikroskopii elektronowej - skaningowej (SEM) oraz spektroskopii z dyspersją energii promieniowania rentgenowskiego (EDS) wykazały przy zastosowaniu każdego z trzech spoiw (AI99,5, AISi5, AlSi12), występowanie od strony tytanu warstwy roztworu stałego na osnowie fazy, stechiometrycznie odpowiadającej kruchej i twardej fazie $\mathrm{TiAl}_{3}$.

Przeprowadzone badania lutospawania metodą TIG oraz metodą MIG prądem przemiennym z pulsacją blach ze stali karoseryjnej ocynkowanej (DC03+ZE) ze stopem aluminium w gat. 6061 (AIMg1Si0,6), przy zastosowaniu spoiw AISi12 i AISi5, pozwoliły na uzyskanie złączy o wymaganej jakości i wytrzymałości zbliżonej do wyżarzonych stopów aluminium. Ponadto doświadczalnie wykazano, że zastosowanie niekorozyjnego topnika fluoroglinianowego, w przypadku lutospawania metodą TIG stali ocynkowanej (DC03+ZE) ze stopem aluminium (AW-6061) podwyższa jakość złączy. Poprawiając warunki zwilżenia spoiwem stali umożliwia stosowanie znacznie mniejszych natężeń prądu spawania $(60 \div 70 \mathrm{~A})$ co ogranicza utlenianie i odparowanie powłok cynkowych. Badania metalograficzne oraz analiza fazowa, wykonane przy użyciu mikroskopu elektronowego - skaningowego (SEM) i spektrometru z dyspersją energii promieniowania rentgenowskiego (EDS) wykazały w badanych połączeniach występowanie na granicach lutospoin od strony stali ciągłych warstw o grubości poniżej $10 \mu \mathrm{m}$, złożonych z roztworów stałych na osnowie kruchych faz międzymetalicznych, odpowiadających stechiometrycznie fazom $\mathrm{FeAl}_{3}, \mathrm{Fe}_{2} \mathrm{Al}_{5}$, FeAl oraz $\mathrm{Fe}_{3} \mathrm{Al}$.

\section{Literatura}

[1] L.A. Dobrzański: Podstawy nauki o materiałach i metaloznawstwo. WNT, Warszawa, 2002

[2] Praca zbiorowa: Poradnik Inżyniera. Spawalnictwo. Tom 1 i 2. WNT, Warszawa, 2004/2005.

[3] Joint publication: Brazing Handbook. 5 ed., AWS, Miami, Florida (2007).

[4] M. Schwartz: Brazing. 2 ed., ASM International, Materials Park, Ohio (2003).

[5] O.M.Barabash, J.N.Koval: Struktura i svojstva metallov i splavov. Naukovaja Dumka, Kijev, (1986).

[6] F.Moller, M.Grden, C.Thomy, F.Vollertsen: Combined laser beam welding and brazing proces for aluminium titanium hybrid structures. Physics procedia, 12, 215 $\div 253$ (2011)

[7] B.K.Sabokar, W.N.Zamkov, L.S.Kiriev: Osobiennostiargonovo - dugovoj idiffuzionnoj svarki titana s aluminiem. Avtomatičeskaja Svarka 538, no. 1, $14 \div 17(1998)$

[8] J.Wilden, J.P.Bergman: Manufacturing of titanium/aluminium and titanium/steel joints by mean of diffusion welding. Welding and Cuting, 3 , no. $5,285 \div 290$ (2004).

[9] S.Chen, L.Li, Y.Chen, J.Huang: Joining mechanism of Ti/Al. dissimilar alloys during laser welding - brazing process. Journal of Alloys and Compounds, 509, 2001, s. 891 $\div 898$.

[10] S.X.Li, X.J.Jing, Y.X.Huang, Y.Q.Xu, C.Q.Zheng, S.Q.Yang: Investigation on TIG arc welding - brazing of Ti/Al dissimilar alloys with Al based fillers.

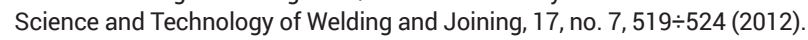

[11] Z.Ma, Ch.Wang, H.Yu, J.Yan, H.Shen: The microstructure and mechanical properties of fluxless gas tungsten arc welding - brazing joints made between titanium and aluminium alloys. Material and Design, 45, 72 79 (2013).

[12] V.R.Ryabov, Welding of aluminium alloys to steels. Harwood Akademic Publishers. USA (1998).

[13] C.Thomy, A.Wirth, M.Kreimeyer, F.Wagner, F.Vollertsen, Joining of dissimilar materials - new perspectives for lightweight design in the transportation industries. Welding on the World, 51, 7, $311-326$ (2007).

[14] A.Winiowski, Structural and mechanical properties of brazed joints of stainless steel and aluminium. Archives of Metallurgy and Materials, 54, $2,523-533$ (2009).

[15] M.J.Zhang, G.Y.Chen, Y.Zhang, K.R.Wu, Research on microstructure and mechanical properties welding-brazing of automotive galvanized steel to aluminum alloy. Materials and Design, 45, $24 \div 30$ (2013).

[16] R.Cao, Q.Huang, J.H.Chen, P.C.Wang, Cold metal transfer spot plug welding of AA6061-T6-to-galvanized steel for automotive applications. Journal of Alloys and Compounds, 585, $622 \div 632$ (2014)

[17] A. Czupryński, D. Janicki: Przyczyny pęknięć lutospoin w złączach różnoimiennych typu aluminium - ocynkowana stal niestopowa, Przegląd Spawalnictwa, vol 88, No 5, 2016.

[18] T. Pfeifer. Analiza wpływu warunków materiałowo technologicznych na własności połączeń elementów z powłokami na bazie cynku, Przegląd Spawalnictwa, vol 87, No 10, 2015. 